ROCZNIKI PEDAGOGICZNE

Tom 13(49), numer $1-2021$

DOI: https://doi.org/10.18290/rped21131.5

\title{
BARTŁOMIEJ GOŁEK
}

\section{PEDAGOGICZNY WYMIAR PRZEŻYCIA ESTETYCZNEGO}

\section{WSTĘP}

W myśl pedagogiki kultury zadaniem wychowania jest przygotowanie człowieka do czynnego i twórczego udziału w życiu kulturalnym przez rozwinięcie jego sił duchowych i wprowadzenie go w świat wartości ponadindywidualnych. Rozwój duchowy jednostki warunkowany jest spuścizną społeczno-kulturową i przyswojeniem sobie obiektywnych wartości kulturowych. Człowiek staje się dojrzałą osobowością dopiero wówczas, gdy uczestnicząc w ponadindywidualnej rzeczywistości świata kultury, przyswajając wartości, przeżywając je i tworząc nowe, organizuje swoje życie wewnętrzne wokół tych wartości. Wychowanie jest zatem procesem wprowadzania jednostki w świat ducha obiektywnego, w świat kultury, jest rozwijaniem dyspozycji zmierzających do internalizowania wartości uniwersalnych (Gajda, 2006). Istotną rolę w odkrywaniu, przeżywaniu i przyswajaniu tychże wartości odgrywać może kontakt człowieka $\mathrm{z}$ dziełami sztuki oraz transcendentalnym pięknem, które te dzieła uobecniają ${ }^{1}$.

Czym jest dzieło sztuki i co je wyróżnia spośród innych dzieł człowieka? Historia sztuki i estetyka - dyscypliny badające fenomen sztuki - nie nakreślają jednej ogólnej definicji dzieła sztuki i ukazują, że pojęcia piękna, sztuki oraz dzieła sztuki zmieniały się na przestrzeni wieków. Starożytny kanon piękna, rozumianego jako zgodność z normą, ustępował w kolejnych

Dr BARTŁomiej GoŁek - Zakład Pedagogiki, Wydział Nauk Społecznych, Akademia Wychowania Fizycznego im. Bronisława Czecha w Krakowie; adres do korespondencji: ul. Śliska 14/99c, 30-516 Kraków; e-mail: bgolek@o2.pl; ORCID: https://orcid.org/0000-0001-6958-5308.

${ }^{1} \mathrm{~W}$ poniższym tekście rozwijam i poszerzam analizy teoretyczne zaprezentowane we wcześniejszym artykule: B. GoŁEK (2013). Rola przeżycia estetycznego w procesie samowychowania człowieka dorosłego. W: A. Gofron, K. MotyL (red.), Podstawy edukacji. Sfera wartości i zasad (s. 143-152). Kraków: Oficyna Wydawnicza „Impuls”. 
stuleciach innym sposobom estetycznego wartościowania. Towarzyszył temu dyskurs filozofów na temat natury i sposobu istnienia wartości estetycznych - spór o ich obiektywizm bądź subiektywizm, absolutyzm bądź relatywizm. Jak pisze Maria Gołaszewska: „Pomiędzy tymi krańcowymi ujęciami, z których jedno traktuje piękno jako ideę, a drugie uznaje jedynie fakt podobania się jako subiektywną reakcję podmiotu, mieści się pogląd, że piękno realizuje się w dziele sztuki. [...] Wartości estetycznych zaczęto szukać przede wszystkim w dziele sztuki, a jeśli poza nim, to jednak zawsze w konkretnych przedmiotach, a nie w ogólnych bytach ani w świecie idei" (Gołaszewska, 1973, s. 11). Zdaniem cytowanej autorki, dzieło sztuki stanowi całość składającą się z różnorodnych elementów, ustrukturyzowanych wedle określonej zasady i istnieje ono o tyle, o ile w świadomości ludzkiej występuje jako przedmiot realizujący wartość estetyczną (Gołaszewska, 1973, s. 209). M. Gołaszewska nawiązuje przy tym do myśli swojego mistrza, Romana Ingardena, który podkreśla, że dzieło sztuki nie jest tylko przedmiotem fizycznym, za jaki zazwyczaj uchodzi, jest czymś więcej: „Dzieło sztuki wykracza jednak zawsze swą strukturą i właściwościami poza to, co jest jego fizyczną podstawą bytową, jakkolwiek własności tej podstawy nie są obojętne dla właściwości dzieła sztuki, które się na nim opiera. Na dzieło sztuki i jego ukształtowanie skierowują się przede wszystkim twórcze akty autora, a kształtowanie podstawy fizycznej dzieła jest jedynie czynnością służebną i dostosowaną do tego, jakie ma być wytworzone przez artystę samo dzieło" (Ingarden, 1970, s. 266-267). Co istotne, dzieło sztuki, będące wytworem intencyjnych czynności swego autora (twórcy), domaga się swoistej konkretyzacji. Filozof tłumaczy: „To zaś, co dzięki odbiorowi dzieła przez perceptora stanowi nie tylko rekonstrukcję dzieła w tym, co efektywnie w nim zawarte, a nadto jego częściowe dopełnienie i zaktualizowanie jego momentów potencjalnych, i co jest przeto niejako wspólnym wytworem autora i perceptora - to konkretyzacja dzieła" (Ingarden, 1970, s. 267). Według R. Ingardena, dzieła sztuki charakteryzuje ta własność, iż na ich podłożu konstytuować się mogą właściwe przedmioty estetyczne, a dzieje się to w trakcie szczególnego procesu przeżywania sztuki przez perceptora (odbiorcę), co przedstawione zostanie w dalszej części tekstu.

Spośród wielu koncepcji estetycznych przytoczyć jeszcze warto - na użytek zamierzonych analiz pedagogicznych - myśl Johna Deweya, który przeciwstawia sztukę naturze i stwierdza, że „Sztuka nie jest czymś naturalnym, lecz przeobrażeniem tego, co naturalne, przez włączenie w nowe zależności” (Cyt. za: Wilkoszewska, 1988, s. 129). Pojęcia sztuki nie należy, 
zdaniem J. Deweya, traktować synonimicznie z pojęciem dzieła sztuki, gdyż to drugie, będące przedmiotowym wytworem sztuki, ma węższy zakres znaczeniowy. Dzieła sztuki są artystycznymi wytworami, posiadającymi określone cechy formalne (wartości artystyczne) nadane im przez artystów. Cechuje je wypracowane mistrzostwo i intencjonalne kształtowanie - artyści potrafią w sposób świadomy i zamierzony kształtować takie przedmioty, nadając im odpowiednią strukturę. Jednak podobnie, jak R. Ingarden, również J. Dewey uważa, że uproszczeniem byłoby utożsamianie dzieł sztuki z fizycznie istniejącymi przedmiotami materialnymi, takimi jak rzeźba, obraz, budowla, książka. Dla J. Deweya dziełem sztuki jest „sposób, w jaki wytwór artystyczny kształtuje doświadczenie i jest w nim obecny" (cyt. za: Wilkoszewska, 1988, s. 47), zaś sama sztuka to ,jakość, która przenika doświadczenie" (cyt. za: Wilkoszewska, 1988, s. 139). Dotykamy tu istoty Deweyowskiej koncepcji estetyki, w centrum której mieści się kategoria doświadczenia, co rozwinięte zostanie w dalszej części tekstu.

Rozumienie dzieła sztuki jako wytworu artystycznego, prowadzącego do doświadczenia estetycznego (przeżycia estetycznego), wydaje się być trafne i taka definicja przyjęta została na potrzeby poniższych rozważań na temat wychowawczych, poznawczych i autokreacyjnych wartości spotkań człowieka ze sztuką. Dzieła sztuki mogą kształtować i wzbogacać nasze doświadczenie i pozostać w tym doświadczeniu na długo obecne, przez to ich przeżywanie prowadzić może do względnie trwałych zmian w naszym systemie postaw i wartości.

Jak zauważył Adam Malinowski, ,[...] obszarem przynależnym sztuce w sposób szczególny jest osobowy wymiar istnienia człowieka. Obszar ten jest podstawowym źródłem fenomenu sztuki, wyróżniając ją spośród innych ludzkich aktywności" (Malinowski, 2000, s. 63). Owy fenomen sztuki, istotowo powiązany z egzystencją człowieka, może dawać szansę na przezwyciężanie niebezpieczeństw cywilizacji XXI wieku, cywilizacji skoncentrowanej na wartościach utylitarnych i technicyzacji wielu obszarów życia społecznego. Kontakt człowieka $\mathrm{z}$ dziełami sztuki, z zawartymi w tych dziełach wartościami, wzmacniać może procesy autokreacji, samokształtowania się, w szczególności kształtować może w jednostce dyspozycję do krytycznego, pogłębionego namysłu nad sobą, światem, złożoną rzeczywistością kulturową. Dlatego warto dziś sięgać po koncepcję wychowania przez sztukę zaproponowaną przed laty przez Herberta Reada, a rozwijaną potem na gruncie teorii wychowania estetycznego. Badaczka tej problematyki, Joanna Torowska, zwraca uwagę na wymowną aktualność myśli pedagogicznej H. Reada. 
Autorka pisze, że H. Read w wydanej w 1943 r. książce Education through art ,[...] głosił ideę obrony czy nawet ocalenia człowieka, zwłaszcza jego wrażliwości i postaw twórczych, w warunkach zagrożenia przez różnego rodzaju siły i mechanizmy wywodzące się ze swoistości współczesnej cywilizacji, która wzmaga niebezpieczeństwo alienacji, dehumanizacji, konformizmu, odbierając człowiekowi jego humanistyczną tożsamość" (Torowska, 2008, s. 49). Tożsamość współczesnego człowieka narażona jest na różnego rodzaju kryzysy, związane m.in. z gwałtownym rozwojem nowoczesnych technologii, napływem wciąż nowych informacji i postępującą dezaktualizacją dotychczasowej wiedzy, wzmagającą się konkurencyjnością i rywalizacją na rynku edukacji i pracy, wyobcowaniem, utratą korzeni. Jak słusznie twierdzi Elżbieta Kukuła, „Technologiczne i społeczne przemiany stworzyły zupełnie nową sytuację. Wychowanie do sztuki i wychowanie przez sztukę staje się pilną koniecznością" (Kukuła, 2000, s. 46). Za sprawą przyspieszonego rozwoju elektronicznych środków masowego przekazu, człowiek współczesny ma coraz większy i coraz łatwiejszy dostęp do dzieł artystycznych z różnych dziedzin. Kontakt ze sztuką i jej przeżywanie chroni jednostki przed zobojętnieniem pod naporem bodźców wytwarzanych przez dzisiejszą cywilizację, może budować porozumienie między ludźmi i służyć rozwijaniu współpracy między nimi (Torowska, 2000). Może wspomagać dialog kultur i kształtować powszechną kulturę pokoju, co zdaje się być zobowiązaniem edukacyjnym na XXI wiek (Wojnar, 2000).

W jaki sposób sztuka może oddziaływać na człowieka i w jakich obszarach rozwoju osobowego kontakt z działami sztuki jest szczególnie pomocny? Na czym polega istota przeżycia estetycznego i w jakim sensie możemy mówić o jego pedagogicznym wymiarze? Próbę odpowiedzi na te i podobne pytania przynoszą zaprezentowane poniżej analizy teoretyczne.

\section{ISTOTA I WIELOWYMIAROWOŚĆ PRZEŻYCIA ESTETYCZNEGO}

Oddziaływanie sztuki na człowieka dokonuje się w toku przeżycia estetycznego, które jawi się jako doświadczenie przewartościowujące wewnętrznie jego uczestnika. Owo przeżycie estetyczne jest podstawą procesu wychowawczego (osobotwórczego) oddziaływania sztuki. Tak pisze o tym Bogusław Bieszczad: „Aby można było mówić o pożądanych [...] skutkach kontaktu jednostki z dziełem artystycznym, musi zaistnieć osobiste przeżycie tej jednostki wynikłe $\mathrm{z}$ wewnętrznego jej kontaktu $\mathrm{z}$ danym zjawiskiem estetycznym. 
Taki kontakt musi też uaktywnić jednocześnie sferę emocji, wyobraźni i intelektu odbiorcy" (Bieszczad, 2016, s. 159). W przywoływanej już we wstępie koncepcji R. Ingardena, dzieło sztuki domaga się dla swej konkretyzacji czynnika istniejącego poza nim samym, to jest perceptora (odbiorcy sztuki). Filozof wyjaśnia: „Znaczy to, że dzięki swej współtwórczej akcji przy odbiorze dzieła perceptor stara się przede wszystkim - jak to się zwykle mówi - odczytać, lub lepiej powiedziawszy: zrekonstruować dzieło w jego efektywnych właściwościach, a czyniąc to zarazem - jakby pod sugestią dzieła dopełnia jego schematyczną budowę, usuwając przynajmniej częściowo luki w określeniu dzieła, a równocześnie aktualizując niektóre jego momenty, będące w stanie potencjalności. Powstaje w ten sposób konkretyzacja dzieła sztuki (Ingarden, 1970, s. 267). Owo odsłanianie się czy też konstytuowanie się dzieła sztuki (przedmiotu estetycznego) dokonuje się stopniowo w trakcie złożonego procesu przeżycia estetycznego.

Roman Ingarden ukazał przeżycie estetyczne jako proces czasowo rozciągły, rozwijający się w wielorako określonych fazach - od zmysłowego spostrzeżenia pewnego realnego przedmiotu do uchwycenia wartości estetycznych w tym przedmiocie zakotwiczonych i ich szczególnego oddziaływania. „Każde w pełni rozwinięte przeżycie estetyczne dokonuje się w mnogości faz, które [...] następują po sobie i prowadzą do ukonstytuowania się przedmiotu estetycznego, a w następstwie do jego bezpośredniego uchwycenia" (Ingarden, 1970, s. 97). Pierwszą fazą jest więc spostrzeżenie realnego przedmiotu (rzeczy, procesu), powodujące, że uderza nas jakaś szczególna jego jakość (np. barwa, akord, rytm itp.), która koncentruje naszą uwagę i pobudza nas w szczególny sposób. Spostrzeżona jakość nie pozwala podmiotowi przeżywającemu pozostać „zimnym”, obojętnym, lecz wprawia go w szczególny stan wzruszenia zwany „emocją wstępną” - stan niedosytu, pożądania, wewnętrznego niepokoju. Owa emocja wstępna, pojawiająca się w strumieniu świadomości człowieka, prowadzi - zdaniem R. Ingardena „[...] do aktywnego zwrócenia się podmiotu ku jakości, która go poruszyła, rozpoczynając tym samym nową fazę przeżycia estetycznego; [...] Zarazem emocja ta pociąga za sobą liczne zjawiska następcze, które odcinają przeżycie estetyczne od wcześniejszych przeżyć perceptora [...] Wskutek tego przeżycie estetyczne tworzy całość odcinającą się od naturalnego biegu życia codziennego, całość, która dopiero ex post włącza się jakoby automatycznie w tok naszego życia" (Ingarden, 1970, s. 98). Dochodzi tu do zamiany zasadniczego nastawienia podmiotu, który doznał emocji wstępnej - z naturalnego nastawienia właściwego życiu praktycznemu lub postawie badawczej 
w postawę specyficznie estetyczną. Powoduje to swoistego rodzaju zahamowanie poprzedniego, „normalnego" toku naszych przeżyć i sposobu zachowania się. To, czym przed chwilą się zajmowaliśmy, traci nagle swą wagę, staje się nieinteresujące, obojętne. Świat realny usuwa się niejako na peryferie świadomości, zaś zainteresowanie podmiotu przeżywającego skierowuje się już nie na rzeczy realne, lecz na to, co na razie czysto jakościowe. Zdaniem R. Ingardena, w późniejszych fazach intensywnego przeżycia estetycznego może dojść nawet do quasi-zapomnienia o świecie realnym. Taka zmiana naszego nastawienia sprawia, że dana jakość, która pierwotnie występowała jako cecha rzeczy spostrzeganej, zostaje wyzwolona $\mathrm{z}$ tej formalnej struktury i na chwilę pozostaje „czystą jakością”, a więc szczególną wartością, która nas ogarnia, zatrzymuje, nasyca. Autor pisze, że „Jakość ta wysuwa się teraz nie tylko na pierwszy plan w polu widzenia (wybija się), lecz zaczyna się zarazem odcinać i wyróżniać od pierwotnego pola teraz już zneutralizowanego spostrzeżenia i kształtuje pewną całość" (Ingarden, 1970, s. 99). Tak oto w toku przeżywania odsłania się przed nami konkretna wartość estetyczna, np. wartość piękna, harmonii, symetrii, tragiczności, komizmu, prostoty, liryzmu. Co ciekawe, owo oglądanie danej jakości przeradza się w pewnego rodzaju delektowanie się nią, a to z kolei - według R. Ingardena - „[...] wywołuje niebawem nowe pożądanie naocznego posiadania estetycznie poruszających nas jakości, których też podmiot przeżywający estetycznie poszukuje w danym bezpośrednio dziele sztuki albo zarysowuje je jedynie w żywym wyobrażeniu" (Ingarden, 1970, s. 99). W ten oto sposób odbiorca - na drodze zaangażowanego przeżywania - konkretyzuje artystyczny wytwór twórcy. W ostatniej fazie przeżycia estetycznego zawarty jest szczególny moment - afirmujący moment stwierdzenia, osadzania w bycie ukonstytuowanego przedmiotu estetycznego: „Zostaje on uznany za coś istniejącego w szczególny sposób" (Ingarden, 1970, s. 102). Ten moment afirmujący (moment uznania wartości) jest dla przeżycia estetycznego istotny. „Jeżeli go brak, to znaczy, że się go nie spełniło i że brak również ukonstytuowanego przedmiotu estetycznego" (Ingarden, 1970, s. 102).

Jak trafnie zauważyła Jadwiga Lach-Rosocha, w koncepcji R. Ingardena doświadczenie estetyczne jest swoistym samowychowaniem, które realizuje się na dwóch poziomach: poziomie przeżywania i poziomie poznania. „Pierwszy to proces twórczy i przeżycie percepcyjne dzieła, drugi - intelektualny eksperyment poznawczy nadający estetycznemu doznaniu rangę doświadczenia życiowego i w pełni komunikatywną postać" (Lach-Rosocha, 2013, s. 278). Podobnie rzecz ujmuje przywoływany wcześniej J. Dewey, dla którego do- 
świadczenie estetyczne jest relacją zachodzącą pomiędzy twórcą lub odbiorcą a dziełem sztuki, relacją podmiotu do dzieła sztuki. Zdaniem tego autora, w doświadczeniu - również tym związanym ze spostrzeżeniem przedmiotu artystycznego - umysł postrzega rzeczy i tworzy o nich pojęcia, następnie powstaje sąd, który jest kombinacją owych spostrzeżonych elementów, kombinacją wydobywającą związki i stosunki zachodzące pomiędzy tymi elementami (cyt. za: Wilkoszewska, 1988, s. 48). Co istotne, doświadczenie estetyczne jest rodzajem doświadczenia rzeczywistego, czyli takiego, które za sprawą równowagi pomiędzy momentami działania i doznawania prowadzi do spełnienia, charakteryzuje się spełnieniem i posiada całościowy charakter, to znaczy spaja poszczególne jego fragmenty w harmonijną całość. Według J. Deweya to, co wyróżnia doświadczenie estetyczne od innych grup doświadczeń człowieka, to jego nadrzędny cel - cel estetyczny (w doświadczeniu praktycznym celem tym będzie osiągnięcie pewnej korzyści, w doświadczeniu intelektualnym - wniosek). Doświadczenie estetyczne nie ma celu poza sobą samym, jest doświadczeniem czystym, a spełnieniem jest tu estetyczne scalenie poszczególnych części. Autor pisze, że „W doświadczeniu zdecydowanie estetycznym dominują cechy, które w innych doświadczeniach są przytłumione. Cechy gdzie indziej podporządkowane, tutaj pełnią funkcję nadrzędną - są to bowiem cechy, które powodują, że doświadczenie samo przez się staje się całkowite i pełne" (cyt. za: Wilkoszewska, 1988, s. 62). Autoteliczność przeżywania sztuki nie wyklucza oddziaływania doświadczenia estetycznego na inne obszary funkcjonowania człowieka. Przeciwnie, zdaniem J. Deweya, doświadczenie estetyczne stawać się może najwyższą sublimacją i spotęgowaniem codziennych doświadczeń życiowych człowieka, a kontakt ze sztuką kształtuje i podtrzymuje w nas zdolność do doznawania świata w całej jego pełni (cyt. za: Wilkoszewska, 1988, s. 138).

$\mathrm{Na}$ wielowymiarowość przeżycia estetycznego i jego autokreacyjny charakter zwrócił też uwagę Władysław Stróżewski (Stróżewski, 2002). Zdaniem tego filozofa, w toku obcowania człowieka $\mathrm{z}$ dziełem sztuki dochodzi do jeszcze jednej istotnej fazy przeżycia aksjologicznego - na ukazujących się wartościach estetycznych mogą nadbudowywać się wartości wyższe, tzw. wartości nadestetyczne, do których należą: piękno, wartości moralne (dobro), wartości prawdy i prawdziwości, wartości istnienia (metafizyczne) oraz wartości sacrum. Dla swojego zaistnienia wartości te wymagają szczególnej wrażliwości ze strony odbiorcy sztuki, szczególnej postawy podmiotu przeżywającego, wymagają fazy intensywnego skupienia i kontemplacji bytu. W. Stróżewski pisze: „Czyste piękno jest w szczególny sposób zaborcze: 
przykuwa do siebie pomimo dystansu, w jakim się objawia, zatrzymuje przy sobie bez reszty. Ale zdarza się, że piękno staje się źródłem niepokoju. Zachwyca, a równocześnie przenosi ów zachwyt poza siebie. Niepokój, który się wtedy rodzi, nie ma nic wspólnego z uczuciem przykrości. Jest to niepokój podniecenia, niepokój bycia na tropie, przybliżania się do tajemnicy, o której się już wie, że jest, że czeka i przyzywa poza siebie i ponad pięknem, choć jeszcze nie została ani odgadnięta, ani nazwana" (Stróżewski, 2002, s. 192). Metafizyczny zachwyt nad pięknem wywołuje w człowieku doświadczenie konieczności, zjednoczenie idealności i faktyczności - zachwycona jednostka czuje, ze coś jest dokładnie tak, jak być powinno. Tak pisał o tym Józef Tischner: „Piękno ukazuje nam nowy niecodzienny poziom bycia i przenosi nas tam, niekiedy mówi się: porywa. Poza nami pozostaje cała proza życia. Przed nami jest już tylko poezja bycia. Piękno wyznacza nowy ośrodek naszemu życiu duchowemu" (Tischner, 2012, s. 120).

Zdaniem W. Stróżewskiego, wspomniane wartości nadestetyczne przysługują tylko niektórym dziełom sztuki, tylko przez niektóre dzieła mogą być odsłonięte czy objawione. Samo przeżycie estetyczne może zaś być pozytywne lub negatywne, o czym M. Gołaszewska pisze następująco: „Nieudane dzieło sztuki lub dzieło wykonane w konwencji obcej, przykrej dla odbiorcy, a także zjawiska rzeczywistości wywołujące przykre wrażenia zmysłowe to miejsca, gdzie powstają przeżycia estetyczne negatywne, jak obrzydzenie, nuda" (Gołaszewska, 1997, s. 226). To spostrzeżenie jest istotne dla analizowania pedagogicznego wymiaru przeżyć estetycznych - wartość wychowawczą i autokreacyjną będą miały takie dzieła sztuki, z którymi obcowanie uruchamiać będzie w jednostce dodatnie przeżycia estetyczne, łączące się z internalizacją wartości transcendentalnych: prawdy, dobra, piękna. Współczesność wykształciła bowiem szereg dzieł natury artystycznej, które, choć wywołują w odbiorcy emocje i zachęcają do refleksji, nie mają potencjału odsłaniania przed człowiekiem wartości wyższych, nie prowadzą nas do realizacji aksjologicznego optimum (Stróżewski, 2002). Zdaniem R. Ingardena, „Jakość estetycznie wartościowa jest jakością, która bądź sama w sobie i przez samą siebie, bądź też jako składnik pewnego zespołu jakości jest estetycznie wartościowa, determinując tym samym jakość odpowiedniej wartości. Prócz tego uwrażliwia ona podmiot na jej percepcję i pobudza go do spełnienia pewnych faz przeżycia estetycznego [...]" (Ingarden, 1970, s. 258-259).

Intensywne przeżywanie wartościowych dzieł sztuki może nam pomagać w wewnętrznej pracy nad sobą, w duchowym rozwoju własnej wrażliwości, $\mathrm{W}$ wydobywaniu drzemiącego $\mathrm{w}$ nas potencjału poznawczego i emocjonalnego. 
Jadwiga Lach-Rosocha, badając fenomenologiczne opisy indywidualnych ludzkich przeżyć estetycznych, dowodzi, iż przeżycia te mają swoisty wymiar pedagogiczny. Autorka twierdzi: ,[...] że przeżycia estetyczne swoje osobotwórcze osiągnięcia zawdzięczają pedagogii wykorzystującej praktycznie wszystkie właściwe sztuce możliwości i sposoby intensyfikowania efektów estetyczno-artystycznego oddziaływania na podmiot. Możliwości te zawierają się w sposobach angażowania uwagi, w formach prezentacji problemów, w strategiach potęgowania odczuć wrażeń, w taktykach epatowania treściami i w technikach inspirowania wyobraźni twórczymi pomysłami” (Lach-Rosocha, 2013, s. 401). W myśl koncepcji wychowania estetycznego, jeśli chcemy pojąć jakąś wartość i prawdziwie jej doświadczyć, musi dokonać się w nas swoiste przeżycie tej wartości. W pełni ukonstytuowane przeżycie aksjologiczne jest tu więc środkiem do dojrzałej internalizacji wartości, ta zaś internalizacja wartości i związane z nią kształtowanie się systemu społeczno-moralnych postaw jest celem naszego osobistego rozwoju. Muszę głęboko przeżyć daną wartość, aby zrozumieć, że wybór tej wartości i jej urzeczywistnianie w codziennym życiu jest dla mnie słuszne i dobre. Kontakt z dziełami sztuki może efektywnie pomagać nam w budowaniu własnego systemu wartości, w samorealizacji, w heroicznym „tworzeniu siebie”. Dzieje się tak jednak tylko wtedy, gdy przeżycia estetyczne stają się osobistą sprawą człowieka, albowiem - jak pisze Joanna Torowska - ,[...] postawa estetyczna rodzi się z żywego stosunku do sztuki; żywym staje się ten stosunek tylko wówczas, gdy sztuka coś znaczy dla człowieka, gdy odpowiada jego przeżyciom, pragnieniom, wątpliwościom, marzeniom, działaniom, planom [...]" (Torowska, 2008, s. 49).

\section{POZNAWCZA I OSOBOTWÓRCZA WARTOŚĆ SZTUKI}

Jak wykazano powyżej, istotną cechą przeżycia estetycznego jest to, że odsłania ono przed swoim podmiotem nie tylko wartości estetyczne (będące tego przeżycia bezpośrednią przyczyną), ale także wartości poznawcze i społeczno-moralne. Sztuka odkrywa przed człowiekiem szereg egzystencjalnych wartości, których umysł nie ogarnia. Poznanie tych wartości opiera się „nie tylko na poznaniu rzeczywistości zewnętrznej, ale również na wglądzie we własne wnętrze, w świat własnej wrażliwości, niepowtarzalnej percepcji świata, wglądzie we własne osobowe potencjały wyzwalające moce intelektualne i fizyczne do kreowania rzeczywistości” (Matwijów, 1994, s. 60). 
Obcowanie z działami sztuki, wytworami ludzkiej myśli i wrażliwości, pomaga $\mathrm{w}$ poznawaniu siebie samego, swych możliwości i ograniczeń. Zdaniem Józefa Tischnera, oczarowany transcendentalnym pięknem człowiek uzyskuje szczególną samowiedzę: „Piękno przewyższa człowieka, odsłania przed nim inny, nieosiągalny świat [...]" (Tischner, 2012, s. 123). Dochodzimy tu do kolejnego pedagogicznego aspektu przeżycia estetycznego, jakim jest samopoznanie oraz pomoc w zrozumieniu otaczającej człowieka, coraz bardziej złożonej rzeczywistości. Przeżywanie sztuki i kontakt z jej wytworami rozszerza zakres naszej wiedzy o świecie i o nas samych. Trafnie dowodzi tego M. Gołaszewska, pisząc, że ,[...] ujmowanie działa sztuki w funkcji poznawczej ma swoje pełne usprawiedliwienie [...]. Sztuka ukazuje świat i działającego w nim człowieka, uwikłanego w rozmaite sploty losów, konfliktów, przeżyć; jest ona zwierciadłem człowieka istniejącego w świecie, w konkretnych warunkach społecznych i historycznych. Odbiorca może w dziele sztuki odnaleźć siebie - swoje własne problemy, które nie ujrzane w sztuce, nie doszłyby, być może do jego pełnej świadomości, nie umiałby sobie z nich zdać sprawy" (Gołaszewska, 1979, s. 41). W innym miejscu cytowana autorka tak wyjaśnia poznawczą wartość sztuki: ,[...] przednaukowe poznanie ludzkie jest niedokładne, nieprecyzyjne, poznajemy rzeczywistość zaledwie w zarysach, zawartość treściowa oraz zakresy i granice naszego poznania są niewyraźne, chwiejne, niejasne [...]. Sztuka stanowi jeden ze sposobów umysłowego oświetlenia faktów, co w efekcie daje pewną amorficzną intuicję poznawczą. Dzieła sztuki są zatem wyrazem raczej niepokoju poznawczego, zwrócenia uwagi na możliwości poznawcze, niż definitywnych rozstrzygnięć (Gołaszewska, 1973, s. 431).

Podobnie rzecz ujmuje Elżbieta Kukuła, pisząc, że „Dzięki kontaktom z dziełami sztuki wzbogaca się zasób naszych doświadczeń, następuje wewnętrzny rozwój. [...] Sztuka uczy widzieć otaczającą rzeczywistość, której samodzielnie ludzie nie potrafią dostrzec, mimo iż na nią patrzą. Kontakty ze sztuką pozwalają także uświadomić sobie to, co zaledwie przeczuwamy a także to, co jest w nas nieuświadomione" (Kukuła, 2000, s. 47-48). Inicjowane przez przeżycie estetyczne samopoznanie to także próba stwierdzenia, na ile wyznawany i akceptowany przeze mnie wzór osobowy zgadza się z moim faktycznym zachowaniem. Dlatego też - jak zauważa M. Gołaszewska - „Dalszą konsekwencją tego, iż sztuka stanowi zwierciadło rzeczywistości, jest jej funkcja osobowościowotwórcza. Dzięki sztuce człowiek dochodzi do wyższego stopnia samowiedzy, co jest znaczącym czynnikiem 
w procesie kształtowania się jego osoby i włączania w nią wartości znajdowanych w sztuce" (Gołaszewska, 1979, s. 42).

Sztuka, oprócz swego zasadniczego wymiaru estetycznego, posiada więc dużą wartość poznawczą, ułatwia i wspiera intelektualne rozpoznanie świata i zachodzących w nim przemian, może być pomocna w procesie odkrywania przez jednostkę wewnętrznych zdolności do kreowania siebie i otoczenia. Kontakt ze sztuką sprzyja procesom poznawania czynnego, czyli takiego, które prowadzi do rozumienia. „W sposób czynny uzyskiwana jest wiedza o tym, co wykracza poza to, co już o tym czymś nam wiadomo, poza to, co możemy dostrzec. Jest ona formą zrozumienia, to znaczy aktywnego, osobistego ujęcia czegoś na różnych poziomach ogólności" (Obuchowski, 1995, s. 178-179). Osoby, mające kontakt ze sztuką, częściej niż inni prezentują kreatywny sposób spostrzegania rzeczywistości, są gotowe znajdować wiele rozwiązań napotykanych problemów bądź zauważać dawne problemy w nowym świetle. Zdaniem Ireny Wojnar, obcowanie ze sztuką przyczyniać się może do integralnego rozwoju osobowości człowieka w trzech następujących obszarach: w sferze intelektualnej - poprzez wzbogacanie wiedzy i osiąganie samodzielności poznawczej, uczenie się krytycznego i osobistego myślenia; w sferze społeczno-moralnej - poprzez wypracowywanie podstaw oceny moralnej, umiejętności rozumienia sytuacji ludzkich, co z kolei prowadzić może do lepszego porozumienia $\mathrm{z}$ innymi; w sferze kształtowania wyobraźni i postawy twórczej - chodzi tu więc o ,[...] takie wzbogacenie osobowości człowieka, by stał się on jej aktywnym współtwórcą, kształtując samego siebie, osiągając stan wyższej, pełniejszej samowiedzy i samourzeczywistnienia" (cyt. za: Matwijów, 1994, s. 60-61). W tym właśnie sensie sztuka i jej przeżywanie, twórczość i kontakt z przedmiotami estetycznymi jawią się jako ważne podłoże procesu kształtowania się człowieka w ciągu całego życia. Implikują taką zmianę na poziomie osobowości człowieka, którą określa się mianem generatywności - to jest zdolność powoływania do życia nowych wytworów i nowych idei oraz tworzenia samego siebie, co powiązane jest $\mathrm{z}$ dalszym rozwojem tożsamości psychospołecznej (Appelt, 2005). Warto więc korzystać $\mathrm{z}$ aksjologicznego potencjału sztuki zarówno w toku organizowanych oddziaływań pedagogicznych na innych, jak i w toku samodzielnej, odśrodkowej i nie wymuszonej zewnętrznymi okolicznościami aktywności wychowawczej i kształcącej.

Kształtować siebie trzeba zaś na każdym etapie własnej biografii, gdyż człowieczeństwo nie jest czymś danym i gotowym, a nasza aksjologiczna istota nie znajduje swej finalnej postaci (Stróżewski, 1992). Absolut sztuki 
ma szansę wzmacniać autokreacyjną kompetencję człowieka, prowadzić do konstruktywnych zmian w jego osobowości. Jak pisze Violetta Przerembska, „[...] kształtowanie dojrzałej, pełnej i odpowiedzialnej osobowości człowieka nie jest możliwe bez włączenia się w świat wartości reprezentowanych przez sztukę, i to nie tylko wartości artystycznych, lecz także poznawczonaukowych, społecznych i moralnych" (Przerembska, 2009, s. 73). Kontakt z dziełami sztuki rozwija nasze zainteresowania, dostarcza nam bodźców do rozwoju poznawczego i emocjonalnego, rozwija w nas zdolność myślenia abstrakcyjnego, odrywa od konkretnego „tu i teraz”, pozwala nam wychodzić poza proste dane doświadczenia. Człowiek, stając się podmiotem estetycznego przeżycia, jest konfrontowany sam z sobą i swoim losem, z własnymi błędami i stratami, taka konfrontacja jest naturalnym zadaniem autokreacji (Pawlak, 2009). Sztuka kształtuje nasz namysł nad światem i jego złożonością, a poprzez swój uniwersalizm próbuje przezwyciężać skróconą perspektywę czasową, znamienną dla epoki transformacji (Brzezińska, 2005). Aktywność kulturalna, poznawanie poszczególnych dziedzin sztuki i świadomy kontakt z jej dziełami, wreszcie próby samodzielnej twórczości artystycznej to skuteczne sposoby na poszukiwanie i znajdowanie tych doświadczeń i działań, które dadzą nam treść i formę do dojrzałego przeżywania własnej egzystencji, pomogą odnaleźć własną tożsamość, odkryć sens życia, skompensować jego braki i niedostatki. Przez wzbudzanie twórczego niepokoju i ukazywanie nieograniczonych możliwości sztuka wyrywa nas z niebezpiecznego samozadowolenia, każe dziwić się światem i szukać dalej, kształtuje w nas głęboki namysł nad istotą i tajemnicą życia.

J. Lach-Rosocha, analizując procesy zachodzące w człowieku pod wpływem jego kontaktu z działami sztuki, trafnie konkluduje: „[...] przeżycia estetyczne są doświadczeniami egzystencjalnymi, w których dochodzi do odkryć uniwersalnych, dokonujących zasadniczych zmian w postrzeganiu rzeczywistości, przewartościowujących relacje intra- i interpersonalne, podważających prawomocność nawykowych sposobów myślenia i odczuwania, rozwiewających tajemnice i problemy życia w estetyczno-artystycznej perspektywie" (Lach-Rosocha, 2013, s. 407). Autorka podkreśla dalej, że wychowawczy potencjał przeżyć estetycznych zawiera się przede wszystkim $\mathrm{w}$ intencjach etycznych, co bierze się z opisanego wcześniej faktu nadbudowywania się wartości moralnych, wartości uniwersalnych na odsłaniających się podczas kontaktu ze sztuką wartościach estetycznych. „W przeżyciach estetycznych uwiarygodnia się prawda, że osobowym stawaniem się nie rządzi konieczność, lecz twórcza zasada wiążąca autokreacyjne aspiracje 
indywidualnego samostwarzania ze światem rzeczywistości kulturowej, w której możliwa jest samoafirmacja" (Lach-Rosocha, 2013, s. 407).

Pedagodzy, badający tę problematykę, dostrzegają w obcowaniu ze sztuką (a szerzej - z dobrami ludzkiej kultury) wielkie możliwości dla dążeń samorealizacyjnych człowieka na każdym etapie jego życia. Irena Wojnar pisze o torii wychowania estetycznego jako o swoistej propozycji edukacyjnej, która, nieustannie poszerzana o nowe przemyślenia i doświadczenia, stała się „[...] konkretyzacją edukacji człowieka, inspirowaną przez alternatywną pedagogikę humanistyczną. Ta pedagogika zajmuje się edukacją i wzbogacaniem człowieka przez jego własne dzieła i przez jego własną aktywność kulturalną, czuwa nad nieustannym stawaniem się człowieka jako istoty myślącej i wrażliwej, kreatywnej i bogatej wewnętrznie" (Wojnar, 2000, s. 147148). Jak twierdzi Bogusława Matwijów: „Sztuka, jako element rzeczywistości kulturowo-społecznej człowieka, posiada z nim relacje dwojakiego rodzaju; z jednej strony jest działaniem, a z drugiej - doznawaniem. Człowiek zarówno może doznawać i być pod wpływem wartości estetycznych, jak i może swe wewnętrzne doznania świata przekształcić w działanie, czyli w formy estetyczne" (Matwijów, 1994, s. 59). Taka postawa estetyczna, jak stwierdza M. Gołaszewska, jest wynikiem świadomych decyzji człowieka, które mogą „powstawać w toku refleksji nad sobą i światem z uwzględnieniem osobistych, jednorazowych doświadczeń, kumulujących się i wytwarzających właśnie postawę estetyczną" (Gołaszewska, 1997, s. 27).

\section{PODSUMOWANIE}

Przedstawiona powyżej analiza wielokierunkowego oddziaływania sztuki na człowieka ukazuje pedagogiczny wymiar przeżycia estetycznego, to jest wymiar związany z wychowaniem, kształceniem i samokształtowaniem się (autokreacją) człowieka. Sztuka kryje w sobie duży potencjał wychowawczy, obcowanie z dziełami sztuki może być efektywnie wykorzystywane w procesie kształtowania dyspozycji poznawczych, postaw moralnych i kompetencji społecznych jednostki. Stymulowanie w toku oddziaływań pedagogicznych wartościowych (pozytywnych) przeżyć estetycznych odgrywa ważną rolę w budowaniu aksjologicznego wymiaru człowieka jako osoby, przeżycia takie inicjują bowiem procesy przeżywania i przyswajania uniwersalnych wartości. Kontakt z działami sztuki rozwijać może kulturę estetyczną człowieka, jego estetyczno-moralną wrażliwość, kształtuje postawy empatii i głębokiego 
namysłu nad problemami ludzkiej egzystencji. Przeżycie estetyczne tworzy horyzont dla zrozumienia siebie i drugiego człowieka, nawet jeśli ten drugi w jakimś obszarze funkcjonowania jest inny, różny ode mnie.

W dyskusji publicznej i w przekazach medialnych podważa się dziś niejednokrotnie znaczenie wiedzy ogólnej w rozwoju człowieka, traktuje się ten rodzaj wiedzy i związane z jej nabywaniem predyspozycje osobowościowe za mniej przydatne w osiąganiu osobistego szczęścia, zwłaszcza na polu zawodowym (Gołek, 2011). Humanistykę zastąpiono technologiami, które są „pożyteczniejsze”, bo mamy z nich pożytki materialne. Pragmatyzm i ciasny utylitaryzm zdominowały różne obszary życia społecznego, również edukację. W mniemaniu znacznej części organizatorów i reformatorów oświaty, twórców programów nauczania pierwsze miejsce należy przyznać wiedzy specjalistycznej, wąskiej wiedzy przedmiotowej, która zapewni absolwentom zajęcie intratnego miejsca na rynku pracy. Sprawy kształtowania dojrzałej i empatycznej osobowości, kształtowania ducha przegrywają dziś w chłodnej kalkulacji zysków i strat. Atmosferę przeciwwagi dla tych tendencji tworzyć może taka formacja duchowa człowieka, która dokonywać się będzie z udziałem całokształtu kultury i jej dóbr. Kontakt z dziełami sztuki, z egzystencjalną i humanistyczną myślą w nich zawartą, wzbudzać może doznania, które ,„...] umożliwiają człowiekowi personalistyczną samokreację we wszystkich wymiarach człowieczeństwa poprzez internalizację urzeczywistnianych w przeżyciach estetycznych wartości natury, kultury i sztuki" (Lach-Rosocha, 2013, s. 453). Warto podkreślać wciąż na nowo „[...] możliwości sztuki w kształceniu uczuć i wyobraźni, myślenia osobistego, umiejętności empatycznych i wrażliwości na drugiego człowieka, rozwijaniu zdolności do ekspresji” (Wojnar, 2000, s. 153). Projektując różnorodne oddziaływania edukacyjne, akcentować warto szczególne znaczenie przeżyć estetycznych w procesie harmonijnego rozwoju człowieka, w procesie przygotowywania jednostki do czynnego uczestnictwa w życiu kulturalnym i społecznym. Co istotne, wychowanie estetyczne, rozumiane jako całościowy proces kształcenia, wychowania i samokształtowania się człowieka na drodze przeżyć estetycznych i interioryzacji związanych z tymi przeżyciami wartości, nie jest tylko sprawą edukacji dzieci i młodzieży. W równie istotnym stopniu winno ono być doświadczeniem osób dorosłych, ułatwiającym rozpoznawanie niejednoznacznej i złożonej rzeczywistości XXI wieku. 


\section{BIBLIOGRAFIA}

Appelt, K. (2005). Środkowy okres dorosłości. Jak rozpoznać potencjał dojrzałych dorosłych. W: A.I. BRZEZIŃSKA (red.), Psychologiczne portrety człowieka (s. 503-552). Gdańsk: Gdańskie Wydawnictwo Psychologiczne.

BIESZCZAD, B. (2016).Wychowanie estetyczne - współczesne dyskursy. W: A. GAwEe, B. BIESZCZAD (red.), Reinterpretacje kontekstów wychowania (s. 147-171). Kraków: LIBRON.

BrzeziŃSKA, A.I. (2005). Jak skutecznie wspomagać rozwój? W: A.I. Brzezińska (red.), Psychologiczne portrety człowieka (s. 683-708). Gdańsk: Gdańskie Wydawnictwo Psychologiczne.

GAJDA, J. (2006). Pedagogika kultury w zarysie. Kraków: Oficyna Wydawnicza „Impuls”.

GoŁAsZewSKA, M. (1997). Estetyka pięciu zmysłów. Warszawa-Kraków: Wydawnictwo Naukowe PWN.

GolaszewsKa, M. (1979). Kultura estetyczna. Warszawa: Wydawnictwa Szkolne i Pedagogiczne.

GoŁaszewska, M. (1973). Zarys estetyki. Problematyka, metody, teorie. Kraków: Wydawnictwo Literackie.

GoŁeK, B. (2011). Miejsce wiedzy ogólnej i wiedzy z pedagogiki ogólnej w systemie wiedzy nauczyciela. W: M. MYszKowsKA-Litwa (red.), Pedagogika ogólna a teoria i praktyka dydaktyczna (s. 221-234). Kraków: Wydawnictwo Uniwersytetu Jagiellońskiego.

GoŁeK, B. (2013). Rola przeżycia estetycznego w procesie samowychowania człowieka dorosłego. W: A. Gofron, K. Motyl (red.), Podstawy edukacji. Sfera wartości i zasad (s. 143152). Kraków: Oficyna Wydawnicza „Impuls”.

IngARDEn, R. (1970). Studia z estetyki. T. 3. Warszawa: Państwowe Wydawnictwo Naukowe.

Kukula, E. (2000). Sztuka w wychowaniu dawniej i dziś. W: K. PANKowsKA (red.), Sztuka $i$ wychowanie. Wspótczesne problemy edukacji estetycznej (s. 38-50). Warszawa: Wydawnictwo Akademickie „Żak”.

Lach-Rosocha, J. (2013). Pedagogia przeżycia estetycznego w wychowaniu czlowieka jako osoby. Kraków: Oficyna Wydawnicza „Impuls”.

MALINOWSKI, A. (2000). O sztuce i edukacji w kontekście osobowego wymiaru istnienia człowieka. W: K. PANKowska (red.), Sztuka i wychowanie. Wspótczesne problemy edukacji estetycznej (s. 59-65). Warszawa: Wydawnictwo Akademickie „Żak”.

MatwiJów, B. (1994). Samokształtowanie się czlowieka $w$ pedagogicznych koncepcjach XX wieku. Kraków: Uniwersytet Jagielloński. Skrypty Uczelniane nr 707.

Obuchowski, K. (1995). Przez galaktykę potrzeb. Psychologia dążeń ludzkich. Poznań: Wydawnictwo „Zysk i S-ka”.

Pawlak, J. (2009). Autokreacja. Psychologiczna analiza zjawiska i jego znaczenie dla rozwoju człowieka. Kraków: WAM.

PRZEREMBSKA, V. (2009). Sztuka i jej wartości wychowawcze w pryzmacie pedagogiki kultury okresu międzywojennego w Polsce (1918-1939). W: M. ZALEWSKA-PAWLAK (red.), Sztuka wobec zakresów wolności człowieka liberalnego. Pedagogiczne rozważania i doświadczenia (s. 67-77). Łódź: Wydawnictwo Uniwersytetu Łódzkiego.

STRÓżEWSKI, W. (1992). W kręgu wartości. Kraków: ZNAK.

STRÓŻEWSKI, W. (2002). Wokót piękna. Szkice z estetyki. Kraków: UNIVERSITAS. 
TorowsKA, J. (2000). Aktualność koncepcji wychowania przez sztukę Herberta Reada. W: K. PANKOWSKA (red.), Sztuka i wychowanie. Wspótczesne problemy edukacji estetycznej (s. 51-58). Warszawa: Wydawnictwo Akademickie „Żak”.

Torowska, J. (2008). Edukacja na rzecz dziedzictwa kulturowego. Aspekty teoretyczne i praktyczne. Kraków: Wydawnictwo Uniwersytetu Jagiellońskiego.

Tischner, J. (2012). Filozofia dramatu. Kraków: ZNAK.

WiLKoszewsKa, K. (1988). Sztuka jako rytm życia. Rekonstrukcja filozofii sztuki Johna Deweya. Kraków: Uniwersytet Jagielloński.

WoJnAR, I. (2000). Humanistyczne intencje edukacji. Warszawa: Wydawnictwo Akademickie „Żak".

\section{PEDAGOGICZNY WYMIAR PRZEŻYCIA ESTETYCZNEGO}

\section{STRESZCZENIE}

Artykuł ukazuje pedagogiczny wymiar oddziaływania sztuki na człowieka. Inicjowane w kontakcie z dziełami sztuki przeżycia estetyczne odgrywają istotną rolę w kształtowaniu systemu postaw i systemu wartości człowieka. W trakcie przeżycia estetycznego odsłaniają się przed jednostką nie tylko wartości estetyczne, ale także wartości poznawcze i społeczno-moralne. Kontakt ze sztuką ułatwia samopoznanie i wspiera intelektualne rozpoznawanie coraz bardziej złożonej rzeczywistości, buduje porozumienie między ludźmi, pomaga w wewnętrznej pracy nad sobą. Wykorzystywanie przeżyć estetycznych w procesach kształcenia, wychowania i samokszatłtowania może być przeciwwagą dla utylitarnych i pragmatycznych tendencji we współczesnej edukacji, sprzyjać może kształtowaniu dojrzałej osobowości.

Słowa kluczowe: sztuka; przeżycie estetyczne; wychowanie przez sztukę.

\section{PEDAGOGICAL IMPACT OF THE AESTHETIC EXPERIENCE}

\section{SUMMARY}

The article presents the pedagogical impact of art on a human being. The aesthetic experience that comes with dealing with pieces of art has a substantial role in creating an axiological human system. In the process of aesthetic experience, not only does an individual discover the aesthetic values, but also cognitive, social and moral ones. Dealing with art facilitates self-discovery and supports intellectual understanding of the complex reality, creates a good rapport between people, helps in working on your inner self. Banausic and pragmatic tendencies may be counterbalanced by using aesthetic experiences in modern education in order to foster the formation of a mature personality.

Keywords: art; aesthetic experience; education through art. 